\title{
Chelated Versus Inorganic Zinc Supplementation in Ruminants
}

\author{
Tariq A Malik*, Shahid H Mir and Ravi P Pal \\ Animal Nutrition Division, ICAR-National Dairy Research Institute, India
}

Submission: October 05, 2017; Published: December 07, 2017

*Corresponding author: Tariq A Malik, Animal Nutrition Division, ICAR-National Dairy Research Institute, Haryana, India,

Email: drtariq093@gmail.com

\begin{abstract}
Chelation is a smart approach of enhancing the bioavailability and retainability of minerals and avoiding any interference stemmed from mineral interactions. Though the rate of absorption of chelated (organic) and inorganic zinc appears to be similar at dietary levels fulfilling the normal body requirements. However, at higher concentration chelated zinc seems to be at an advantage, as its supplementation would increase plasma and tissue zinc concentration than that of inorganic zinc. Supplementation of organic zinc may show better results in terms of average daily gain, feed intake, milk production, udder health, energy utilization from feed and proportion of different volatile fatty acids in rumen. However, the concept of superiority of chelated minerals needs further elucidation.
\end{abstract}

Keywords: Bioavailability; Chelates; Inorganic zinc; Organic zinc

\section{Introduction}

Chelates, otherwise known as organic minerals, are the coordinated compounds formed as a result of reaction between the element and ligand. The ligand forms a heterocyclic ring around the element and claws it firmly by means of coordination bonds. Chelation was first discovered by Werner in 1894, however, the name Chelate was coined by Morgan and Drew in 1920's. The word chelate comes from the greek word "chel" meaning "claw", indicating the element is held or clawed tightly by the ligand.

\section{Classification of Chelates}

The Association of American Feed Control officials classified chelates into five categories [1]

\section{Metal amino acid complexes}

Formed by complexing of soluble metal salts with amino acids (more than one type) without any due consideration to the molar ratio. e.g., copper amino acid complex.

\section{Metal amino acid chelates}

Complexes of metal ions and amino acids (more than one type) with a molar ratio of one mole of metal to three moles (preferably two) of amino acids. The weight of the hydrolyzed amino acids must be 150amu (approx.) and the total molecular weight of the chelate must be within 800 amu e.g. copper amino acid chelate, zinc amino acid chelate.

\section{Metal polysaccharide complexs}

Formed by reaction of mineral ions from soluble salts with a polysaccharide solution e.g. copper polysaccharide complex, zinc polysaccharide complex.

\section{Metal proteinates}

Chelates of mineral ions from soluble salts with amino acids and/or partially hydrolysed protein e.g. copper proteinate chelate, zinc proteinate chelate.

\section{Metal (specific amino acid) complexs}

Products are obtained by complexing of soluble metal salts with specific amino acids (only one type of amino acid) e.g. copper lysine chelate, zinc methionine chelate.

\section{Mode of Action}

The mode of action of chelates is still not elucidated with clarity. The purpose of using organic chelates is to increase the bioavailability of minerals by increasing their absorption and avoiding any interference with other minerals. Chelates are believed to remain stable in rumen and get absorbed intact post-ruminally in the intestine by the process different from that of inorganic minerals. They are absorbed largely via unsaturable passive diffusion (Paracellular route) or the process mediated by their ligands like amino acids (Intra- 
cellular route). The chelated minerals reaching plasma are intact while the dissociation takes place at the site of utilization of mineral.

\section{Organic vs Inorganic Zinc}

Organic minerals after absorption may enter into different pools within the body than inorganic forms. It is believed that zinc is present in the body mainly in organic form hence the diet with organic zinc will provide better bioaccessibility of the mineral element, however, there are well defined organic or protein bound and inorganic or free ion pools of zinc in the body. Free zinc ions are present in a very small proportion in the cells. Excess of free zinc ions is either forced to bind with metallothionein (zinc binding protein) or is excreted out of the cells. Zinc from the organic source is released slowly over the period of time within the cells, thus, giving enough time to cells to regulate the free zinc ions produced as a result of degradation of organic compounds within cytoplasm, hence zinc from organic sources are retained quite efficiently. Spears [2] had predicted much earlier that organic minerals are metabolized differently than that of inorganic forms and organic minerals are retained better than inorganic minerals, though the exact mechanism is still not clear.

\section{Bioavailability}

Bioavailability along with retainability of zinc as defined by the plasma and tissue concentration appears to be more in chelated zinc than in inorganic zinc. Neathery [3] found that organic radio labeled zinc (65Zn) from corn was $40 \%$ more efficiently retained than the inorganic radio labeled zinc $(65$ $\mathrm{ZnCl} 2$ ) fed to cattle. Similarly, cattle supplemented with zinc in the from a zinc methionine, zinc lysine or zinc proteinate have higher serum and liver zinc concentrations than cattle fed a similar amount of zinc from zinc oxide or zinc sulphate [4]. Relative zinc bioavailability for zinc Proteinate, zinc Aminoacids, and zinc Methionine was reported to be 130, 110 and 113, respectively, taking zinc Sulphate as standard [5]. Rojas [6] observed higher $(\mathrm{P}<.05)$ zinc accumulation in kidneys, liver, and pancreas of lambs upon supplementation of zinc lysine compared to zinc methionine, zinc sulphate, and zinc oxide. However, mean zinc concentration of bone, bone marrow, hooves, skin, cornea and muscular tissue was similar. The zinc lysine treated lambs also showed higher tissue metallothionein concentrations. This led to the conclusion that organic sources of zinc have equal or greater availability than the most available inorganic source and may be metabolized differently in some tissues. However, the similar experiment when repeated on cattle did not show any significant difference in the zinc concentration of serum and other body tissues probably due to high amount of zinc in the basal diet.

The rate of absorption of organic and inorganic forms of zinc might be similar at dietary levels fulfilling the normal body requirements as no significant differences could be observed in plasma or tissue concentrations. However, at higher concentration organic zinc seems to be at advantage as its supplementation would increase the concentration of zinc in tissues and plasma more than that of inorganic zinc. Thus, retention and absorption of zinc is supposedly more in organic form at higher concentration while at lower concentrations zinc homeostasis mechanism would stabilize the plasma and tissues zinc concentration through changes in absorption and fecal endogenous excretion of zinc.

\section{Effect on Rumen Fermentation}

Ruminal soluble zinc concentrations tend to be higher in animals supplemented with organic zinc than inorganic zinc, however, total VFA concentrations appears to be lesser in organic zinc supplemented animals. This suggests that organic zinc may interact to a lesser degree than inorganic zinc in the rumen to form insoluble complexes. Moreover, the free zinc ions from inorganic source may become a part of rumen microbiota resulting in low concentrations of rumen soluble zinc. Ruminants supplemented with zinc proteinate, zinc polysaccharide, zinc methionine or zinc glycine thus have higher ruminal soluble zinc concentrations than those receiving inorganic zinc. Extremely high concentration $(<1000 \mathrm{ppm})$ of zinc sulphate has direct effect on rumen protozoa which affect the degradation of feed protein indirectly. A higher dietary concentration of organic zinc like Zinc methionine increases the molar proportion of propionate and tends to decrease the molar proportions of butyrate and valerate. Moreover, molar proportion of propionate tends to be higher with organic zinc (Zinc methionine) supplementation than inorganic zinc supplementation (Zinc Sulphate). The increased propionate and decreased butyrate concentrations observed in organic zinc supplemented ruminants indicates an improvement in microbial efficiency of energy utilization [7].

In-vitro addition of zinc chloride to rumen liquor significantly $(\mathrm{p} \leq 0.001)$ decreased the TVFAs and total protozoa count in sheep, while in case of goats a significant increase in ammonia along with a drastic decrease $(\mathrm{p} \leq 0.001)$ of total protozoal count was observed. Additionally ALT, AST and GDH activity was enhanced significantly with inhibition of GGT activity, both in sheep and goats [8]. Inorganic zinc ions tend to have an inhibitory effect on the cellulolytic enzymes produced by the bacteria. Thus it may decrease the utilization of cellulose by rumen bacteria at higher concentrations. Cellulolytic bacteria counts have also shown a decreasing trend with the increase in the ionic zinc levels in-vitro. In an interesting study by Černík [9], goats fed different organic and inorganic forms of zinc reported significant differences in the length, width and intensity of keratinisation of ruminal papillae. The kids supplemented with zinc in the form of zinc oxide had well developed papillae, reflecting the fact that some portion of zinc in the diet should necessarily be in inorganic form. 


\section{Effect on Production Performance}

Supplementation of organic zinc produced better results than inorganic forms in terms of average daily gain and feed intake in steers, growing kids, calves and pigs and milk production in goats, ewes, and cattle [10]. In a twelve-trial summary on lactation performance and udder health by Kellog [11], it was reported that cows fed organic zinc produced more milk, energy-corrected milk and fat-corrected milk than nonsupplemented cows, however, milk composition remained the same between treatment and control cows. Somatic cell count also decreased in organic zinc supplemented cows. The summary concluded that organic zinc supplementation may enhance lactation performance and udder health of milch animals. Pechova [12] reported a negative correlation between the somatic cell count and zinc concentration in milk of cattle and goats with similar efficiency of zinc incorporation into milk from different sources viz; organic and inorganic. Concentration of zinc in the milk tends to increase by zinc supplementation irrespective of the source; however, results are not consistent [13]. Supplementation of zinc might change the fatty acid profile of milk but doesn't have any significant impact on the amino-acid profile. Inorganic zinc tends to increase the trans-fatty acids in the milk fat [14].

\section{Conclusion}

There is continuous upsurge in the use of chelated minerals by the farmers. However, the superiority of chelated minerals is not always proved by the experiments. There is plethora of literature supporting the use of organic zinc and its high efficacy than inorganic zinc but sufficient literature is also available which considers organic zinc in no way better than inorganic forms. At this point in time a caution is must while favoring any of the opinion. The research on chelated minerals has been substantial in recent years; such researches are largely funded by the companies producing mineral chelates. So the results of these studies must be interpreted with open mind.

\section{References}

1. AAFCO (2000) Association of American Feed Control Officials.
2. Spears JW (1989) Zinc methionine for ruminants: Relative bioavailability of zinc in lambs and effects of growth and performance of growing heifers. J Anim Sci 67(3): 835-843.

3. Neathery MW, Miller WP, Blackmon DM, Gentry RP, Jones IB (1973) Absorption and tissue zinc content in lactating dairy cows as affected by low dietary zinc. J Anim Sci 37: 848-852.

4. Wang RL, Liang JG, Lu L, Zhang LY, Li SF, et al. (2013) Effect of zinc source on performance, zinc status, immune response, and rumen fermentation of lactating cows. Biol Trace Elem Res 152(1): 16-24.

5. Cao J, Henry PR, Guo R, Holwerda RA, Toth JP, et al. (2000) Chemical characteristics and relative bioavailability of supplemental organic zinc sources for poultry and ruminants. J Anim Sci 78(8): 2039-2054.

6. Rojas LX, McDowell LR, Cousins RJ, Martin FG, Wilkinson NS, et al. (1995) Relative bioavailability of two organic and two inorganic zinc sources fed to sheep. J Anim Sci 73(4): 1202-1207.

7. Arelovich HM, Amela MI, Martínez MF, Bravo RD, Torrea MB (2014) Influence of different sources of zinc and protein supplementation on digestion and rumen fermentation parameters in sheep consuming low-quality hay. Small Ruminant Research 121(2-3): 175-182.

8. Mousa SA (2014) Influence of in vitro addition of metal ions salts on rumen fermentation parameters and selected ruminal enzymes activity in sheep and goats. Life Science Journal 11(4): 198-203.

9. Černík J, Pavlata L, Pechová A, Mišurová L, Jokverová O, et al. (2013) Effects of peroral supplementation of different forms of zinc on the ruminal mucosa of goat kids -A morphometric study. Acta Veterinaria Brno 82: 399-403.

10. Ashmead HD, Samford RA (2004) Effects of metal amino acid chelates or inorganic minerals on three successive lactations in dairy cows. International Journal of Applied Research in Veterinary Medicine 2(3): 181-188.

11. Kellogg DW, Tomlinson DJ, Socha MT, Johnson AB (2004) Effects of zinc methionine complex on milk production and somatic cell count of dairy cows: Twelve-Trial Summary. The Professional Animal Scientist 20(4): 295-301.

12. Pechova A, Misurova L, Pavlata L, Dvorak R (2009) The influence of supplementation of different forms of zinc in goats on the zinc concentration in blood plasma and milk. Biol Trace Elem Res 132(1-3): 112-121.

13. Sobhanirad S, Carlson D, Kashani RB (2010) Effect of zinc methionine or zinc sulfate supplementation on milk production and composition of milk in lactating dairy cows. Biol Trace Elem Res 136(1): 48-54.

14. Faulkner MJ (2016) Effects of trace mineral supplementation in lactating dairy cattle. Dissertation. The Ohio State University.

\section{Your next submission with Juniper Publishers will reach you the below assets}

- Quality Editorial service

- Swift Peer Review

- Reprints availability

- E-prints Service

- Manuscript Podcast for convenient understanding

- Global attainment for your research

- Manuscript accessibility in different formats

( Pdf, E-pub, Full Text, Audio)

- Unceasing customer service

Track the below URL for one-step submission https://juniperpublishers.com/online-submission.php 